\section{Evaluation of the impact of a nutritional program for undernourished children in Brazil}

\author{
Avaliação do impacto de um programa \\ de suplementação alimentar para crianças \\ desnutridas no Brasil
}

Iná S. Santos 1

Denise P. Gigante 1

Denise C. Coitinho 2

Hinke Haisma 1

Neiva C. J. Valle 1

Gicele Valente 1

\footnotetext{
1 Departamento de Medicina Social, Universidade Federal de Pelotas, Pelotas, Brasil.

2 Departamento da Nutrição, Faculdade de Ciência da Saúde, Universidade de Brasília, Brasília, Brasil. de Pelotas. C. P. 464

Pelotas, RS 96001-970, Brasil. inasantos@uol.com.br
}

\begin{abstract}
To assess the effectiveness on child growth and body composition of a supplementary feeding program (Milk Supplement Program), a prospective, controlled study was conducted in Northeast Brazil. When entering the Program, children from 10 municipalities with the highest coverage rates in the Program (intervention group) were compared to non-beneficiary children from 10 municipalities with the lowest coverage rates (control group). A total of 219 children aged 6-18 months were enrolled. At entry, both groups were comparable in terms of age, sex, and nutritional status. There were frequent gaps in delivery of the supplement, no extra milk was provided to siblings less than 5 years of age, intra-household redistribution of milk was high, and maternal compliance with recommendations was low. Adjusted analyses by multilevel modelling showed average changes in weight, length, weight-age and length-age Z-scores, and \% body water (deuterium method), at 6 months, of $1.53 \mathrm{~kg}, 6.34 \mathrm{~cm}$, $0.33,0.05$, and $1.11 \%$ respectively among supplemented children as compared to $1.54 \mathrm{~kg}, 6.5 \mathrm{~cm}$, $0.26,0.07$, and $4.10 \%$ among controls, with no statistically significant difference between groups. Thus, the Program failed to compensate for $n u-$ tritional deficiencies in undernourished children in Northeast Brazil.
\end{abstract}

Nutrition Programmes; Infant Nutrition; Body Composition

\section{Introduction}

Malnutrition is often portrayed as part of a vicious circle that also includes poverty and disease, the three components being interrelated and each contributing to the occurrence and persistence of the others. Provision of supplementary foods has been a component of numerous nutritional programs by government and nongovernmental organizations in many countries as a strategy for dealing with the problem 1 .

The Brazilian National Food Supplement Program for Malnourished Children and Pregnant Women at Risk (otherwise known as the Milk Supplement Program) is a supplementary nutritional program introduced in 1993 by the Federal government, targeting undernourished children 6 to 23 months of age below the 10th percentile in the weight-for-age index 2 . The Program's strategy is based on distribution of $120 \mathrm{~g}$ / day of powdered milk plus $24 \mathrm{ml} /$ day of cooking oil to be added to the prepared milk, aimed at boosting its energy content. The supplement has been estimated to provide more than $100.0 \%$ of the protein and about $60.0 \%$ of the daily energy needs of children from 6 to 23 months of age. Half liter of pasteurized whole milk/day (or $60 \mathrm{~g} /$ day of milk powder) is also supposed to be distributed to all household members under 5 years of age to avoid intrafamily distribution of the supplement for the undernourished child. 
The Milk Program is a free food supplementation program combined with basic health actions. Undernourished children are identified through the Feeding and Nutritional Monitoring System (SISVAN - a government system for nutritional monitoring of children under five years) acting at primary health care facilities where the food supplement is distributed. In 2000 , the Program covered 856,614 beneficiaries in the country, with a total expenditure of US\$ 57.5 million. The objective of this study was to assess the impact (effectiveness) of the Milk Program on child growth and body composition, as well as the level of maternal compliance with recommended use of the supplement.

\section{Material and methods}

This was a prospective controlled study with intervention and control areas compared before and after the intervention. The study was conducted in the State of Alagoas in Northeast Brazil. The Northeast was selected because this is the region with the highest undernutrition and poverty rates. Alagoas was selected because it was the State within the Northeast region where the program showed the best process indicators (number and speed of municipalities adhering to the Program).

For sample size calculations, the significance level was set at $5 \%$ (one-tailed test), statistical power at $80 \%$, and standard deviation between groups for weight gain at $0.17 \mathrm{~kg} 3$, while municipalities (counties) were defined as the unit of study. For detecting a difference in weight gain of $150 \mathrm{~g}$ between the intervention and control groups, ten municipalities in each group were required. Approximately ten children were selected per municipality.

The ten municipalities exhibiting the best coverage in the Program were selected for the intervention group; the ten neighboring and comparable municipalities with the lowest rates were selected as controls. Comparability was ascertained by using a survival index for children under six years of age created by UNICEF and the Brazilian Institute of Geography and Statistics 4 in 1991, by which Brazilian municipalities were classified. The index was composed from the following variables: proportion of children under six living in families where the head-of-household received $\leq 1$ minimum wage per month (approximately U\$80), proportion of children under six living in families where the male head had less than one year of schooling, proportion of children under six living in families where the female head had less than one year of schooling, and proportion of children under six living in households with inadequate water supply. Eighty-two per cent of the municipalities in the State of Alagoas, with $56 \%$ of the children under six years, were classified as having the most precarious conditions for child survival. Coverage was estimated as the difference between the number of undernourished children (as detected by SISVAN) and the number of children reached by the Program.

In the 20 selected municipalities, mothers and their 6-18-month-old children attending primary health care facilities and followed-up by community health agents were identified. In each high-coverage municipality, the first 10 children entering the Milk Program or already enrolled in it for as long as one month were selected for the "intervention" (supplementation) group. In each of the ten low-coverage municipalities, ten children below the $10^{\text {th }}$ percentile of weight-for-age index were selected as controls (non-supplementation group). Control children were chosen among those that were underweight but had not been selected to receive the food supplement. The decision on inclusion in the Program was made by local Program managers, independently of the study team. The main reason for an underweight child not being enrolled in the Program was the insufficient amount of supplement available at the municipal level to include all local children who needed it. Field work lasted 12 months: from May to November 2001, to completion of the enrolment and baseline phase; and from November 2001 to May 2002, for the follow-up data collection (second visit).

At entry and at the end of six months, a structured pre-tested questionnaire was used by trained field workers to interview mothers in both groups, at the child's household. At baseline, socioeconomic and demographic family data were collected. Data on child health (prevalence of diarrhea, upper respiratory symptoms, hospitalizations, and immunization status), feeding practices, weekly consumption of local food (beans, rice, cassava, cassava flour, sweet potato, vegetables, cow's milk, and "gogó", a formula milk thickened with cassava flour), and a 24-hour dietary recall history were explored at the two visits. Children from both groups were weighed naked using portable spring hanging 
scales with an accuracy of $100 \mathrm{~g}$, and their length in a recumbent position measured to the nearest mm using especially designed length boards. Standardized procedures were used in all measurements 5 . The National Center for Health Statistics 6 growth data were used as the references.

Total body water was determined by dilution of an orally administered dose of $99.8 \%$ deuterium oxide $\left(2 \mathrm{H}_{2} \mathrm{O}\right)$. At the two visits, children from both groups received a standard dose of $1 \mathrm{~g}$ of deuterium oxide. Saliva samples were collected before dosing, as well as at 3 and 4 hours after dosing. $2 \mathrm{H}$ level in the saliva samples was measured by gas-isotope-ratio mass spectrometry 7,8 . Deuterium dilution space was calculated from the average of two post-dose saliva samples by the plateau method. The isotope dilution space $(\mathrm{N}, \mathrm{kg})$ was calculated using equation 1.

$\mathrm{N}=(\mathrm{WA} / 1000 \mathrm{a})\left(\mathrm{d}_{\mathrm{a}}-\mathrm{d}_{\mathrm{t}}\right) /\left(\mathrm{d}_{\mathrm{s}}-\mathrm{d}_{\mathrm{p}}\right)$

Where $W$ is grams of water used to dilute the dose water; $A$ is the amount of dose water administered; $a$ is grams of dose water used in the dilution; $d$ is the isotope level of the diluted water (subscript $a$ ); the tap water used in the dilution (subscript $t$ ); the post-dose physiological specimen (subscript $s$ ); and the pre-dose physiological specimen (subscript $p$ ). Deuterium dilution space was converted to total body water by dividing by 1.041 to correct for in vivo isotope exchange 9 .

Concurrent enrollment of the child in any other feeding program was checked at the second visit for both groups. Information on process indicators (access, amount of supplement delivered, and compliance with inclusion criteria) were collected for the intervention group only, to assess the Program implementation characteristics 10 . Reported maternal compliance and availability of the supplement in the household were checked at the follow-up visit for the intervention group only. Information on illnesses, hospitalizations and immunization status was collected for both groups at the two visits.

The study protocol was approved by the Institutional Review Board/Ethics Committee of the School of Medicine at the Federal University in Pelotas, Brazil, and by the Alagoas State Secretariat of Health. The research procedures, including deuterium administration and saliva sampling, involved minimal risk 11 . Individual informed consent was obtained from the mother/caregiver during the home visits before the interview.

Supplemented and non-supplemented children were compared in terms of baseline de- mographic and socioeconomic indicators. In the six-month period, the following outcomes were compared: change in weight, length, weight-for-age Z-score (WAZ), height-for-age Z-score (HAZ), and body composition (\% body water) from the first to the second visit. Crude and adjusted linear regression analyses were carried out at the municipal level using multilevel modeling. The highest level was the municipality and the second, the child/family. This approach ensures that the interdependence between children living in the same municipality is taken into account. Data were analyzed with the MLn package (Multilevel Models Project, Institute of Education, London, United Kingdom).

\section{Results}

A total of 219 children were enrolled: 114 receiving the supplement and 105 controls. However, to prevent the effect of misclassification error 12, 28 children were excluded for being above the 10th percentile of the weight-for-age index at enrolment (fifteen supplemented and thirteen non-supplemented). Analyses were restricted to 191 children who met the inclusion criterion satisfactorily. From the first to the second visit, seventeen children were lost (six supplemented and eleven controls), mainly due to change of address to a different city. Two children died, both in the supplemented group. No migration from control to intervention group occurred during the study period.

At study entry, statistically significant differences were observed between the groups regarding some socioeconomic characteristics (Table 1). As compared to controls, supplemented children belonged to families with lower incomes; their parents had less schooling; and they lived in households with poorer conditions (housing and sewage disposal). However, history of low birth weight $(<2,500 \mathrm{~g})$ was more frequent among controls (Table 2). Nutritional indicators in Table 2 show that mean WAZ, HAZ, and WHZ scores of supplemented and nonsupplemented children, as well as percentage of body water, were similar at baseline. Half of the children in both groups were stunted (lengthfor-age index under the third percentile).

At entry, current breastfeeding was more frequent among supplemented children than controls $(20.2 \%$ versus $18.5 \%)$ but the difference was not statistically significant. For those already weaned by enrolment, median duration of breastfeeding had been two months for both groups. Approximately one-fourth and one- 
Baseline demographic and socioeconomic characteristics of children in study on the impact of a food supplement program. Alagoas State, Brazil, 2001.

\begin{tabular}{|c|c|c|c|}
\hline Baseline characteristic & $\begin{array}{l}\text { Supplemented } \\
\mathrm{n}=99(\%)\end{array}$ & $\begin{array}{l}\text { Non-supplemented } \\
n=92(\%)\end{array}$ & $\mathrm{p}$ \\
\hline Sex & & & 0.8 \\
\hline Male & $45(45.5)$ & $44(47.8)$ & \\
\hline Female & $54(54.5)$ & $48(52.2)$ & \\
\hline Age in months (mean $\pm \mathrm{SD}$ ) & $11.51 \pm 3.01$ & $11.76 \pm 3.47$ & 0.6 \\
\hline $6-11.9$ & $50(50.5)$ & $45(48.9)$ & 0.9 \\
\hline $12-18$ & $49(49.5)$ & $47(51.1)$ & \\
\hline Maternal age in years $[n=188]^{*}($ mean $\pm S D)$ & $26.8 \pm 7.6$ & $25.7 \pm 8.4$ & 0.3 \\
\hline$<20$ & $16(16.5)$ & $25(27.5)$ & 0.4 \\
\hline $20-24$ & $32(33.0)$ & $25(27.5)$ & \\
\hline $25-29$ & $14(14.4)$ & $15(16.5)$ & \\
\hline $30-34$ & $16(16.5)$ & $12(13.2)$ & \\
\hline$\geq 35$ & $19(19.6)$ & $14(15.4)$ & \\
\hline Number of siblings & & & 0.4 \\
\hline 0 & $21(21.2)$ & $27(29.3)$ & \\
\hline 1 & $24(24.2)$ & $21(22.8)$ & \\
\hline 2 & $21(21.2)$ & $21(22.8)$ & \\
\hline$\geq 3$ & $33(33.3)$ & $23(25.0)$ & \\
\hline $\begin{array}{l}\text { Family monthly income (times the prevailing } \\
\text { minimum wage) }[n=190]^{\star}\end{array}$ & $0.85 \pm 0.70$ & $1.17 \pm 1.03$ & 0.01 \\
\hline$<0.5$ & $34(34.7)$ & $21(22.8)$ & $0.03^{* *}$ \\
\hline $0.5-0.9$ & $24(24.5)$ & $25(27.2)$ & \\
\hline $1-1.4$ & $27(27.6)$ & $21(22.8)$ & \\
\hline$\geq 1.5$ & $13(13.3)$ & $25(27.2)$ & \\
\hline Mother's years of schooling $[n=187]^{*}$ & $1.8 \pm 2.4$ & $2.8 \pm 3.4$ & 0.02 \\
\hline Illiterate & $49(50.5)$ & $36(40,0)$ & $0.09 * *$ \\
\hline $1-3$ & $24(24.7)$ & $22(24.4)$ & \\
\hline$\geq 4$ & $24(24.7)$ & $32(35.6)$ & \\
\hline Father's years of schooling $[n=152]^{*}$ & $1.4 \pm 2.2$ & $2.4 \pm 2.9$ & 0.02 \\
\hline Illiterate & $47(59.5)$ & $30(41.1)$ & $0.02^{\star \star}$ \\
\hline $1-3$ & $17(21.5)$ & $19(26.0)$ & \\
\hline$\geq 4$ & $15(19.0)$ & $24(32.9)$ & \\
\hline Type of housing $[n=190]^{\star}$ & & & 0.02 \\
\hline Well-built & $83(83.8)$ & $86(94.5)$ & \\
\hline Sub-standard & $16(16.2)$ & $5(5.5)$ & \\
\hline Treated water supply in the household & & & 0.1 \\
\hline Yes & $54(54.5)$ & $60(65.2)$ & \\
\hline No & $45(45.5)$ & $32(34.8)$ & \\
\hline Sewage disposal $[n=190]^{\star}$ & & & 0.02 \\
\hline Sewer & $22(22.4)$ & $32(34.8)$ & \\
\hline Septic tank & $25(25.5)$ & $32(34.8)$ & \\
\hline Pit latrine & $25(25.5)$ & $11(12.0)$ & \\
\hline None & $26(26.5)$ & $17(18.5)$ & \\
\hline
\end{tabular}

* There were missing values on this variable;

** Linear trend test. 
Nutritional characteristics of supplemented and non-supplemented children at baseline. Alagoas State, Brazil, 2001.

\begin{tabular}{|c|c|c|c|}
\hline Nutritional characteristic & $\begin{array}{l}\text { Supplemented } \\
n=99(\%)\end{array}$ & $\begin{array}{l}\text { Non-supplemented } \\
n=92(\%)\end{array}$ & $\mathbf{p}$ \\
\hline Birth weight in grams $[n=160]^{*}($ mean $\pm S D)$ & $2965.33 \pm 589.64$ & $3089.20 \pm 634.77$ & 0.2 \\
\hline$<2.500$ & $12(15.2)$ & $17(21.0)$ & \\
\hline $2.500-2.999$ & $19(24.1)$ & $14(17.3)$ & \\
\hline $3.000-3.499$ & $38(48.1)$ & $25(30.9)$ & \\
\hline$\geq 3.500$ & $10(12.7)$ & $25(30.9)$ & 0.01 \\
\hline Weight (in grams)** & $7.21 \pm 1.18$ & $7.34 \pm 1.21$ & 0.4 \\
\hline Length (in $\mathrm{cm}$ ) ** & $68.53 \pm 4.64$ & $68.96 \pm 4.81$ & 0.5 \\
\hline Weight-for-age Z-score ${ }^{\star \star}$ & $-2.28 \pm 0.71$ & $-2.17 \pm 0.70$ & 0.3 \\
\hline Height-for-age Z-score** & $-2.07 \pm 1.12$ & $-2.01 \pm 1.01$ & 0.7 \\
\hline Weight-for-height Z-score** & $-1.04 \pm 0.87$ & $-1.00 \pm 0.87$ & 0.7 \\
\hline Weight-for-age Z-score ${ }^{\star \star \star}$ & & & 0.3 \\
\hline Under P3 & $66(66.7)$ & $5(58.7)$ & \\
\hline From P3 to P10 & $33(33.3)$ & $38(41.3)$ & \\
\hline Height-for-age Z-score ${ }^{\star \star \star}$ & & & 1.0 \\
\hline Under P3 & $50(50.5)$ & $46(50.0)$ & \\
\hline From P3 to P10 & $49(49.5)$ & $46(50.0)$ & \\
\hline Body water $(\%) *, * \star[n=76]$ & $80.6 \pm 21.5$ & $78.4 \pm 13.1$ & 0.6 \\
\hline
\end{tabular}

* There were missing values on this variable.

** Values are mean \pm standard deviation.

$\star \star *$ Values are number of children and proportion in $\%$.

third of children from the intervention and control groups, respectively, were fully weaned by one month of age.

Daily dietary pattern in both groups at the two visits indicated a monotonous consumption of few types of food: cow's milk, "gogó”, rice, and beans. At the second visit, daily consumption of cow's milk among supplemented children was more frequent than among controls (98.9\% x 92.7\%; p = 0.05). Intake of "gogó”, on the other hand, was reported more frequently by mothers of controls $(76.8 \%)$ as compared to supplemented children $(60.9 \% ; \mathrm{p}=0.03)$. Consumption of chicken liver, egg yolk, and green leafy vegetables was hardly mentioned by mothers at baseline. The number of children consuming fruits, fruit juices, and meat at least once a week was low and similar in the two groups at both visits. At baseline, only vegetables were consumed more frequently by children from the control group $(47.8 \%$ versus $32.3 \%$; $\mathrm{p}=$ $0.04)$. At the second visit, the statistical difference between groups in number of children receiving fruit juices, meat, and vegetables was borderline ( $\mathrm{p}=0.05 ; 0.07$; and 0.08 , respectively) in favor of the non-supplemented group.
Daily dietary intake as assessed by a 24 hour dietary recall history (Table 3 ) showed no differences between groups at baseline. However, at follow-up the total amount of energy consumed by supplemented children on the day before the interview was significantly lower than for controls $(\mathrm{p}=0.004)$.

Diet on the day before the interview in both groups at the two visits was predominantly milk: milk was the main source of energy, protein, and calcium intake. At baseline, supplemented children consumed an average of $301.05 \pm$ $188.69 \mathrm{kcal} / \mathrm{d}$ from milk (compared to $280.28 \pm$ $206.32 \mathrm{kcal} / \mathrm{d}$ by controls). Milk also provided nearly $90.0 \%$ of the calcium, more than $50.0 \%$ of the protein, and about two-thirds of the zinc and vitamin A retinol equivalents consumed per day by children from both groups.

At baseline, prevalence of diarrhea on the day of interview was $13.1 \%$ among supplemented children and $19.6 \%$ among controls $(p=0.2)$. Point prevalence of diarrhea was higher on the day of the second visit $(25.0 \%$ versus $30.5 \%$ in the supplemented and control groups, respectively; $p=0.5$ ). Symptoms of acute respiratory infection in the previous week were reported 
Mean daily energy and nutrient intake and standard deviation for supplemented and non-supplemented children at baseline and at 6-month follow-up, as assessed through 24-hour dietary recall. Alagoas State, Brazil, $2001-2002$.

\begin{tabular}{|c|c|c|c|c|c|c|}
\hline \multirow{2}{*}{ Nutrient* } & \multicolumn{2}{|c|}{ Baseline } & \multicolumn{2}{|c|}{ Follow-up } & \multirow[t]{2}{*}{$p^{\star \star}$} & \multirow[t]{2}{*}{$p^{\star \star \star}$} \\
\hline & $\begin{array}{l}\text { Supplemented } \\
\qquad(n=99)\end{array}$ & $\begin{array}{l}\text { Non-supplemented } \\
\qquad(\mathrm{n}=92)\end{array}$ & $\begin{array}{l}\text { Supplemented } \\
\qquad(\mathrm{n}=91)\end{array}$ & $\begin{array}{l}\text { Non-supplemented } \\
\qquad(\mathrm{n}=81)\end{array}$ & & \\
\hline Total energy intake $(\mathrm{kcal} / \mathrm{d})$ & $815.88 \pm 376.15$ & $858.75 \pm 417.16$ & $749.39 \pm 296.59$ & $890.14 \pm 330.84$ & 0.4 & 0.004 \\
\hline Protein $(g / d)$ & $24.84 \pm 14.80$ & $24.10 \pm 13.91$ & $25.74 \pm 13.47$ & $29.67 \pm 14.69$ & 0.7 & 0.07 \\
\hline Lipids (g/d) & $24.54 \pm 13.61$ & $23.70 \pm 14.56$ & $21.64 \pm 11.97$ & $23.19 \pm 11.66$ & 0.7 & 0.4 \\
\hline Carbohydrates (g/d) & $125.87 \pm 66.21$ & $139.86 \pm 76.07$ & $114.04 \pm 49.04$ & $142 \pm 58.78$ & 0.2 & 0.001 \\
\hline Calcium (mg/d) & $652.04 \pm 366.53$ & $601.93 \pm 408.14$ & $593.32 \pm 348.42$ & $648.28 \pm 357.87$ & 0.4 & 0.3 \\
\hline Iron (mg/d) & $2.37 \pm 1.79$ & $2.52 \pm 1.96$ & $2.82 \pm 2.13$ & $3.26 \pm 2.40$ & 0.6 & 0.2 \\
\hline Zinc (mg/d) & $3.13 \pm 2.28$ & $2.90 \pm 2.17$ & $3.08 \pm 2.10$ & $3.64 \pm 2.71$ & 0.5 & 0.1 \\
\hline Retinol (mg/d) & $331.65 \pm 272.26$ & $295.88 \pm 264.70$ & $300.83 \pm 340.48$ & $317.94 \pm 273.86$ & 0.3 & 0.7 \\
\hline
\end{tabular}

* Values are mean \pm standard deviation:

** Difference between groups at baseline;

*** Difference between groups at follow-up

by about $40.0 \%$ of mothers from both groups at the two visits. Previous hospitalization was reported equally by mothers of supplemented and non-supplemented children at both visits. At baseline, only $52.5 \%$ of supplemented children and $45.7 \%$ of controls were fully immunized for their age. At the follow-up visit, immunization was complete in nearly $80.0 \%$ of children in both groups.

The supplement (18 packages of $200 \mathrm{~g}$ of powdered milk and $900 \mathrm{ml}$ of cooking oil) was delivered at health centers, generally once a month. However, nearly $50.0 \%(n=44)$ of the 91 mothers reported gaps in delivery. Among these, $36.0 \%(n=16)$ failed to receive the supplement more than twice during the six-month period. Concerning compliance, the index child was the only person in the household consuming the supplement in only $32.5 \%$ of the cases. A range of 1-3 other children and 1-2 adults were said to be sharing the milk with the child. Families of beneficiary children did not receive the extra amount of milk targeted for household members less 5 years of age, thus contradicting the Program guidelines. The majority of the mothers $(63.2 \%)$ reported not using the vegetable oil as recommended: instead of adding it to the milk, the oil was used for cooking family meals. At the second visit, when mothers were asked to show the milk from the Program that was still available in the household, more than $1 / 3(35.0 \%)$ had nothing left. For $33.8 \%$ of the families, the amount of milk received was only sufficient for less than three weeks.

During the six-month period, supplemented children gained on average a total of $1.53 \mathrm{~kg}$ in weight and $6.34 \mathrm{~cm}$ in length (Table 4$)$. Non-supplemented children gained $1.54 \mathrm{~kg}$ and $6.57 \mathrm{~cm}$, with no statistically significant difference between groups. No differences were observed in the means or changes in the WAZ, HAZ, or WHZ scores. Percentages of body water were statistically similar in the two groups $(p=0.5)$.

Both groups improved body weight between the first and second visit: one-fourth of the supplemented children and more than $1 / 3$ of the controls were above the $10^{\text {th }}$ percentile of weight-for-age index at the second visit.

Crude and adjusted coefficients of the Program's effect on anthropometric and body composition changes were calculated. Crude coefficients showed a non-significant effect of the Program on the outcomes over the six-month period. Adjusted analysis controlling for child birth weight, parental years of schooling, monthly family income, type of housing and type of sewage disposal did not change the results, indicating that the observed absence of impact from the Program was not due to a negative confounding effect from these socioeconomic characteristics.

\section{Discussion}

This study was an assessment of the impact (effectiveness) of a Brazilian governmental food supplementation program (the Milk Program) on physical growth and body composition in undernourished children less than two years of age. The Milk Program presented some positive aspects. For example, the observed socioeco- 
Nutritional characteristics of supplemented and non-supplemented children at follow-up. Alagoas State, Brazil, 2002

\begin{tabular}{|c|c|c|c|}
\hline Nutritional characteristic & $\begin{array}{l}\text { Supplemented } \\
\qquad(\mathrm{n}=91)\end{array}$ & $\begin{array}{l}\text { Non-supplemented } \\
\qquad(\mathrm{n}=81)\end{array}$ & $p$ \\
\hline Weight (in grams)* & $8.82 \pm 1.20$ & $8.99 \pm 1.07$ & 0.3 \\
\hline Weight change (in grams)* & $1.53 \pm 0.78$ & $1.54 \pm 0.78$ & 0.9 \\
\hline Length (in $\mathrm{cm}$ )* & $75.16 \pm 4.32$ & $75.83 \pm 4.48$ & 0.3 \\
\hline Length change (in $\mathrm{cm})^{\star}$ & $6.34 \pm 2.82$ & $6.57 \pm 3.04$ & 0.6 \\
\hline Weight-age Z-score* & $-1.94 \pm 0.81$ & $-1.85 \pm 0.85$ & 0.4 \\
\hline Weight-age Z-score change* & $0.33 \pm 0.71$ & $0.26 \pm 0.73$ & 0.5 \\
\hline Height-age Z-score* & $-2.01 \pm 1.13$ & $-1.89 \pm 1.16$ & 0.5 \\
\hline Height-age Z-score change* & $0.05 \pm 0.98$ & $0.07 \pm 0.97$ & 0.9 \\
\hline Weight-height Z-score* & $-1.02 \pm 0.83$ & $-0.99 \pm 0.83$ & 0.8 \\
\hline Weight-height Z-score change* & $0.02 \pm 1.02$ & $-0.01 \pm 1.05$ & 0.8 \\
\hline Weight for age & & & 0.2 \\
\hline Under P3 & $47(47.5)$ & $36(39.1)$ & \\
\hline From P3 to P10 & $27(27.3)$ & $22(23.9)$ & \\
\hline Over P10 & $25(25.3)$ & $34(37.0)$ & \\
\hline Height for age & & & 0.4 \\
\hline Under P3 & $42(42.4)$ & $43(46.7)$ & \\
\hline From P3 to P10 & $24(24.2)$ & $15(16.3)$ & \\
\hline Over P10 & $33(33.3)$ & $34(37.0)$ & \\
\hline Body water $(\%)[n=71]$ & $84.7 \pm 35.2$ & $79.9 \pm 23.4$ & 0.5 \\
\hline
\end{tabular}

* Values are means \pm standard deviations.

nomic imbalance between groups highlighted that in settings with scarce resources (as was the case), screening and selection of beneficiary children by health services measurably benefited those with the worst social conditions. Also, from the perspective of Program targeting, only $13.0 \%$ of the beneficiaries failed to meet the inclusion criterion and were thus above the 10th percentile in the weight-for-age index. Quality and reliability of equipment, lack of training, and political issues were probably concurrent reasons for this finding.

There was no detectable impact of the Milk Program on child weight, length, or body composition during the six-month observation period. However, this evaluation has some limitations that should be considered when examining the results. A randomized, blinded, controlled experiment would be the ideal study design to prove efficacy or effectiveness of an intervention 13 . Within a randomized study, the Program would be the only difference between the two groups, and any impact on nutritional status in beneficiaries could be reliably attrib- uted to the program supplement. However, ethical issues prevented randomization. It would be unethical to deprive undernourished children of the potential benefit of the supplement. A "natural experiment" 13 was the methodological alternative adopted for assessing the Program's effectiveness. As a consequence of nonrandomization, the desirable similarity of distribution of confounding characteristics between groups could not be guaranteed, and control children, although undernourished and poor, belonged to families with slightly better social conditions than the supplemented group. However, the controlled design of this evaluation, the multilevel approach used to analyze data, and the adjustment for potential confounders would have allowed detection of a direct impact by the Program, if it actually existed.

To understand the observed results of this evaluation, two major sets of issues must be considered: the type of food provided and the delivery system used to assure that the food reached the intended beneficiaries. It is well 
known that as a rule, the best service delivery system will have the desired positive impact on children's nutritional status only if the foods that are offered are nutritionally adequate or if the nutritional advice is well conceived. Appropriate nutritional supplements or feeding guidelines by themselves are insufficient to ensure improved nutritional outcomes if there are structural or process constraints to their successful delivery 15 .

Regarding the first issue, was it reasonable to expect any effects from the Milk Program? Probably yes. The supplement (milk and vegetable oil) could provide approximately $800 \mathrm{kcal}$, $30 \mathrm{~g}$ protein, 1 ,094g calcium, $0.56 \mathrm{mg}$ iron, $4 \mathrm{mg}$ zinc, and $336 \mathrm{mg}$ retinol per day in addition to regular meals. Daily needs for children 6-23 months of age are, respectively, $1,170 \mathrm{kcal}, 10.9 \mathrm{~g}$, 350-525g, 6mg, 6.5mg, and 400mg 16. However, theoretical benefit does not suffice to support public health decisions. In fact, as shown through the analyses of the 24-hour dietary recall histories, milk was the basic (not an additional) food in the diet. Rather than supplementing diet, the supplement simply displaced the intake of other foods. An intriguing question is whether such other foods would be available to the child in the absence of the supplement. The Milk Program may have accounted for the anthropometric and body composition indices attained by supplemented children, comparable to those achieved by the control group, despite their initial socioeconomic disadvantages.

Concerning the second issue, supply and utilization of the supplement, this study showed that the provision of milk and vegetable oil was not conducted regularly by the Program managers. Gaps in delivery were reported by nearly $50.0 \%$ of the mothers, thereby preventing their full access to the Program. Regarding utilization, it was clear at the second visit that the mean intake of calories $(270 \mathrm{kcal} / \mathrm{d})$ and nutrients $(14.7 \mathrm{~g}$ protein, $524.4 \mathrm{~g}$ calcium, $0.26 \mathrm{mg}$ iron, $1.87 \mathrm{mg}$ zinc, and $179 \mathrm{mg}$ retinol) from milk were considerably lower than the amount made available from the supplement, indicating major under-utilization by beneficiary children.

Maternal compliance is essential for the success of this type of program. An example was a non-controlled assessment of the effect of the Milk Program in Rio de Janeiro, Brazil, from 1994 to 1996 17. Only children under the third percentile of weight-for-age indicator at study entry and adhering to the Program for at least one year were eligible for the study. In the sample, the probability of a child remaining in the Program at 12 months of follow-up, avoiding dropout, was $60.9 \%$. Mean variation of weight- for-age index after one year of follow-up was 0.464 (95\%CI: 0.41-0.52), indicating a positive impact of the Program on nutritional status of children with more compliant mothers.

Although the Program was planned to provide food to household members less than five years of age, in practice this was not happening. As a result, the index child had to share the supplement with other children and even with adults in the household. Non-compliance with this guideline by Program managers was probably associated with observed under-utilization of the supplement by the index child. High intra-household redistribution of the supplement and maternal non-compliance with the use of vegetable oil, contradicting Program orientation, probably played an important role in the results. Reasons for the high rate of rejection of adding the vegetable oil to the formula milk is an issue deserving further exploration. An intervention study in Brazil targeting children less than two years of age at risk of undernutrition 18 was successful in recommending the addition of vegetable oil to children's meals, an approach which could be tried by the Milk Program as an alternative for enhancing energy density in the food.

Effectiveness in improving child nutrition has been demonstrated in a large number of full-scale nutrition programs by government and nongovernmental organizations 1 . However, few evaluations have successfully demonstrated effects that were clearly attributable to specific nutritional activities. As observed in this study, $25.3 \%$ of the supplemented children recovered from undernutrition during followup. In the absence of a control group, it would have been impossible to distinguish Program impact from regression to the mean. Regression to the mean is a phenomenon observed when individuals in the extreme of a distribution are selected for treatment and follow-up 19. In fact, in normal infants the percentage of total body water at twelve months is some $60.0 \%$, with $80.0 \%$ of fat-free mass 20 . Although total body water was probably overestimated in the study sample due to the plateau method used for its calculation 21 , the figure of $80.0 \% \mathrm{ob}$ served, close to the $75.0 \%$ normally observed at birth, indicates that these infants had hardly any fat, and that body mass was practically equal to fat-free mass. After stratifying according to nutritional status at study entry, children below the 3rd percentile (P3) of weight-for-age index, supplemented or not, presented the same evolution in six months: more than $50.0 \%$ remained under $\mathrm{P} 3,1 / 5$ improved weight to between P3-P10, and 22.0\% recovered from un- 
derweight (> P10). However, children at risk of underweight (between P3-P10) at enrolment evolved differently, whether they were supplemented or not. The proportion of non-supplemented children who recovered to $>\mathrm{P} 10$ was twice that of the supplemented group $(57.9 \%$ and $30.0 \% ; \mathrm{p}=0.02$ ).

To summarize, the observed lack of impact of the Milk Program on child nutrition was probably caused by problems in implementation. Frequent gaps in delivery of the supplement and failure to provide the extra amount of milk to contacts of the index child led to in- tra-familial redistribution of the supplement. This fact, in addition to low maternal compliance with the recommended use of vegetable oil in the formula milk, resulted in low intake of energy and nutrients by the beneficiary child, ultimately translated into absence of Program impact on child nutrition. The results of this study emphasize the importance of a control group and the collection of information on program process of supplement delivery and supplement utilization by the beneficiary child, when assessing the impact of nutritional interventions.

\section{Resumo}

Um estudo prospectivo, controlado foi realizado no Nordeste do Brasil para avaliar a efetividade de um programa de suplementação alimentar (Programa do Leite) sobre crescimento infantil e composição corporal. Ao ingressar no programa, crianças de dez municípios com as maiores taxas de cobertura do programa (intervenção) foram comparadas a crianças não-beneficiárias de dez municípios com as menores taxas de cobertura (controle). Um total de 219 crianças de 6-18 meses de idade foram arroladas. Ao entrar no estudo, ambos os grupos eram comparáveis quanto a sexo, idade e estado nutricional. Houve freqüentes falhas na entrega do suplemento, não foi fornecido leite para os familiares menores de cinco anos, a redistribuição intradomiciliar do leite foi alta e a adesão materna ao recomendado, baixa. Análises ajustadas por modelos multiníveis mostraram variações em peso, comprimento, escore $Z$ peso-idade, comprimento-idade e água corporal (método deutério), em seis meses, respectivamente de 1,53kg; 6,34cm; 0,33; 0,05 e 1,11\%, entre as suplementadas; contra $1,54 \mathrm{~kg} ; 6,57 \mathrm{~cm} ; 0,26 ; 0,07$ e 4,10\% entre as controles, sem diferença estatisticamente significativa entre os grupos. Conclui-se que o programa não foi efetivo para compensar deficiências nutricionais no nordeste brasileiro.

Programas de Nutrição; Nutrição Infantil; Composição Corporal

\section{Contributors}

I. S. Santos planned the study methodology and field work logistics, conducted the analyses, and drafted the manuscript. D. P. Gigante assisted in coordinating the data collection, analysis, and drafting of the manuscript. D. C. Coitinho participated in the study planning and site selection, in addition to contributing with ideas for the manuscript. H. Haisma participated in the study planning in relation to application of the isotope and ideas for the article. N. C. J. Valle participated in the database analysis phase and discussion of the findings. G. Minten coordinated the field work and helped draft the article.

\section{Acknowledgements}

This evaluation was supported by the Brazilian Ministry of Health (FAU/FNS 964/00) and the International Atomic Energy Agency (RLA 7/008). The authors are thankful to Dr. Dale Schoeller from the University of Wisconsin, USA, for measurements and interpretation of isotope data on body composition. 


\section{References}

1. Department of Child and Adolescent Health and Development, World Health Organization. A critical link: interventions for physical growth and psychological development. Geneva: World Health Organization; 1998.

2. Brasil. Plano de combate à fome e à miséria princípios, prioridades e mapa das ações de governo. Brasília: Comissão Especial para Propor Medidas de Combate à Fome, ao Desemprego e à Recessão; 1993.

3. Victora CG, Barros FC, Halpern R, Menezes AMB, Horta BL, Tomasi E, et al. Longitudinal study of the mother and child population in an urban region of Southern Brazil, 1993: methodological aspects and preliminary results. J Public Health 1996; 30:34-45.

4. Instituto Brasileiro de Geografia e Estatística. Municípios brasileiros: crianças e suas condições de sobrevivência. http://www.ibge.gov. br (accessed on $16 / \mathrm{Feb} / 2004)$.

5. Cameron N. The measurement of human growth. Beckenham: Croom Helm; 1984.

6. National Center for Health Statistics. Growth curves for children birth-18 years. Hyattsville: National Center for Health Statistics; 1997. (US Department of Health, Education and Welfare Publication 78-1650).

7. Coward A, Cole T. Precision and accuracy of the doubly labeled water energy expenditure by multipoint and two-point methods. Am J Physiol 1992; 263:E965-73.

8. Schoeller DA, Colligan AS, Shriver T, Avak H, Bartok-Olson C. Use of an automated chromium reduction system for hydrogen isotope ratio analysis of physiological fluids applied to doubly labeled water. J Mass Spectrom 2000; 35:1128-32.

9. Racette SB, Schoeller DA, Luke AH, Shay K, Hnilicka JH, Kushner RF. Relative dilution spaces of $2 \mathrm{H}-$ and $18 \mathrm{O}$-labeled water in humans. Am J Physiol 1994; 267:E585-90.

10. Donabedian A. The quality of care. How can it be assessed? JAMA 1988; 260:1743-8.
11. World Health Organization, Council for International Organization of Medical Sciences. International ethical guidelines for biomedical research involving human subjects. Geneva: World Health Organization; 1993.

12. Rothman KJ, Greenland S. Modern epidemiology. Philadelphia: Lippincott-Raven Publishers; 1998.

13. Habicht JP, Victora CG, Vaughan JP. Evaluation designs for adequacy, plausibility and probability of public health programme performance and impact. Int J Epidemiol 1999; 28:10-8.

14. Kleinbaum DG, Kupper LL, Morgenstern H. Epidemiologic research: principles and quantitative methods. New York: Van Nostrand Reinhold; 1982.

15. World Health Organization. Complementary feeding of young children in developing countries: a review of current scientific knowledge. Geneva: World Health Organization; 1998.

16. Food and Agriculture Organization/World Health Organization/United Nations University. Energy and protein requirements. Geneva: World Health Organization; 1985. (WHO Technical Report Series 724).

17. Castro IRR. Efetividade da suplementação alimentar na recuperação de crianças desnutridas: avaliação do programa "Leite é Saúde" (PLS) no município do Rio de Janeiro [Tese de Doutorado]. São Paulo: Faculdade de Saúde Pública, Universidade de São Paulo; 1999.

18. Santos I, Victora CG, Martines J, Gonçalves H, Gigante DP, Valle NJ, et al. Nutrition counseling increases weight gain among Brazilian children. J Nutr 2001; 131:2866-73.

19. Kirkwood BR. Essentials of medical statistics. Oxford: Blackwell Scientific Publications; 1988.

20. Butte NF, Hopkinson JM, Wong WW, O'Brian Smith E, Ellis KJ. Body composition during the first 2 years of life: an updated reference. Pediatr Res 2000; 47:578-85.

21. Davies PS, Wells JC. Calculation of total body water in infancy. Eur J Clin Nutr 1994; 48:490-5.

Submitted on 12/Nov/2003

Final version resubmitted on 26/Feb/2004

Approved on 29/Mar/2004 